\title{
O QUE OCORREU APÓS O EPISÓDIO DE LACI DE ARAÚJO EM 2008? A HOMOSSEXUALIDADE DISCUTIDA NAS FORÇAS ARMADAS DO BRASIL
}

\author{
WHAT OCCURRED AFTER THE EPISODE OF LACI DE ARAÚJO IN 2008? \\ HOMOSEXUALITY DISCUSSED IN THE ARMED FORCES OF BRAZIL
}

\author{
Douglas Verbicaro Soares ${ }^{\mathrm{I}}(\mathbb{0}$ \\ Rafaela Demétrio ${ }^{\mathrm{II}}$ (1) \\ Rafael Morais ${ }^{\mathrm{III}}$ (i)
}

\footnotetext{
${ }^{\mathrm{I}}$ Universidade Federal de Roraima (UFRR), Boa Vista, RR, Brasil. Doutor em Direito.

E-mail: douglas_verbicaro@ yahoo.com.br

${ }^{\text {II }}$ Universidade Federal de Roraima (UFRR), Boa

Vista, RR, Brasil. Acadêmica de Direito. E-mail:

rafaelademetrioc@gmail.com

\author{
III Universidade Federal \\ de Roraima (UFRR), Boa \\ de Direito. E-mail: \\ rafaelcamposm@gmail.com
}

Vista, RR, Brasil. Acadêmico
}

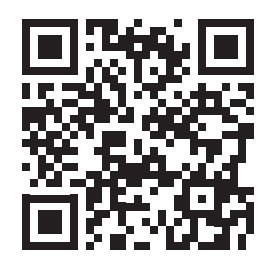

DOI: http://dx.doi. org/10.31512/rdj.v20i37.43

Recebido em: 05.09.2019

Aceito em: 05.042020

\begin{abstract}
Resumo: $\mathrm{O}$ artigo versa sobre a homossexualidade nas Forças Militares do Brasil, enfatizando o notório caso de Laci de Araújo, envolvido em uma polêmica com repercussão nacional após o relato nos meios de comunicação de que o ex-militar mantinha uma relação homoafetiva com outro militar e que estariam sofrendo discriminação por parte da Instituição Militar. $\mathrm{O}$ episódio permitiu um questionamento social em temas de aceitação e negação de militares homossexuais servirem às Forças Armadas no/ país. Para esse tema foi trabalhado no estudo o artigo 235 do Código Penal Militar - CPC, que até a atualidade possui uma tipificação que condena e discrimina a prática da relação homoafetiva, em desacordo com as previsóes constitucionais. Foi realizada uma investigação bibliográfica para a metodologia do estudo. A investigação conclui pela existência de ideais preconceituosos que vem discriminado, ao longo dos tempos, as pessoas homossexuais no âmbito militar.
\end{abstract}

Palavras-chave: Militares. Diversidade sexual. Discriminação.

Abstract: The article deals with homosexuality in the military of Brazil, emphasizing the notorious case of Laci de Araújo, involved in a controversy with national repercussions after media reports that the former had a same-sex relationship with other military and that would be suffering discrimination on the part of the military establishment. The episode allowed social questioning on themes of acceptance and denial of homosexual military personnel serve the armed forces in the country. For this theme was worked in the study article 235 of the Criminal Military Code, which to the present has a type that condemns and discriminates against the practice of samesex relationship, at odds with the predictions. A literature search was performed for the methodology of the study. The research concludes by biased ideals that comes broken down, throughout the ages, gay people within the military.

Keywords: Military. Sexual diversity. Discrimination. 


\section{Consideraçóes iniciais}

O estudo objetiva evidenciar a homossexualidade dentro das as Forças Armadas no país, em destaque, após os 11 (onze) anos do episódio do casal de ex-militares homossexuais, que relataram em sua época (2008), nos meios de comunicação, sofrer preconceitos e discriminações no âmbito militar, em especial no Exército.

$\mathrm{O}$ estudo procurou retratar a situação da homossexualidade dentro das Instituiçóes Militares. Assim, foram feitas certas indagaçóes, como por exemplo: Como a homossexualidade é vista dentro da organização militar? $O$ fato de um militar ser homossexual implicaria em um empecilho para desenvolver o trabalho militar? Como é vista a homossexualidade dentro do espaço das Forças Armadas Brasileiras? Ser homossexual é proibido por alguma normativa das Forças Armadas Brasileiras?

Para o trabalho foi pensada uma pesquisa multidisciplinar, dando destaque às ciências sociais em busca de explicaçôes acerca do tema. $\mathrm{O}$ artigo foi divido em cinco partes, a primeira tratando das Forças Armadas e, também, sobre a presciência constitucional no âmbito militar, com o labor de proteção da defesa do país e os dispositivos fundamentais presentes no ordenamento jurídico nacional. A segunda parte do estudo versou sobre a Constituição de 1988 e o período de transição entre a ditadura e democracia. No terceiro momento se retratou as açóes, tanto positivas como as negativas quanto à aceitação/ negação de militares com uma orientação homossexual em distintos países. A quarta parte se concentrou no desenvolvimento do tema sobre a situação da homossexualidade entendida dentro das Forças Armadas Brasileiras. A última seção trabalhou com a explicitação do dispositivo do CPM, em especial o artigo 235.

\section{As Instituiçóes Militares do Brasil}

No Brasil, as Forças Armadas são divididas e compostas pelos órgãos militares do Exército, os da Marinha e os da Aeronáutica (SENADO FEDERAL, 2018). São instituiçóes nacionais permanentes regulares e que, também, devem por meio de parâmetros constitucionais, cuidar e defender o país no que diz respeito a sua seguridade territorial, assim como na manutenção de seus poderes constitucionais (DEFESA, 2019). Essas forças estão subordinadas ao Ministério de Defesa do Brasil e expressam a identidade nacional (JANOWITZ, 1990, p. 175).

O forte ideário sobre a masculinidade, assim como preceitos heteronormativo e impositivo presentes na sociedade brasileira, acabam implementando dentro das Forças Armadas um forte pensamento discriminatório e de não aceitação de homossexuais pertencentes ao quadro de militares (VERBICARO SOARES, 2015, p. 624). Para a explicitação de algumas dessas condutas discriminatórias, um episódio de 2010, quando 
um militar, cita-se o General Raymundo Nonato de Cerqueira Filho (O GLOBO, 2010), fez algumas consideraçóes sobre a homossexualidade na esfera militar: "que soldados não obedecem a comandantes homossexuais, as atividades desempenhadas pelas Forças Armadas não são adequadas à homossexuais" (GAZETA DO POVO, 2010).

Após os 11 (onze) anos do caso Laci de Araújo, posturas preconceituosas e discriminatórias continuam presentes em falaçóes que estigmatizam os homossexuais, como a do vice-presidente da República Antonio Hamilton Mourão: "sou contrário a um ativismo gay que queira impor isso como um modo de vida. O camarada é homossexual, ele vive a vida dele. Não precisa querer impor aquilo para os demais" (UOL, 2018) ou "apenas ninguém deve procurar impor seu modo de vida aos outros" (BBC BRASIL, 2018).

As referências explicitadas por integrantes de destaque no Governo, assim como dentro das Instituiçóes Militares são alarmantes, pois como representantes públicos e formadores de opiniâo, geram uma ideia que condena a homossexualidade (CEZÁRIO; KOTLINSKI; NAVARRO, 2007, p. 37), portanto, induzem a coletividade à visão de discriminação para uma diversidade sexual que deixou de ser considerada uma doença desde os anos 90 (do século passado), quando Organizaçôes Internacionais e Nacionais deram início à despatologização da homossexualidade (LIONÇO, 2008, p. 18).

Com esses argumentos, busca-se contestar a primeira pergunta do artigo: Como a homossexualidade é vista dentro da organização militar? Ponderar sobre homossexualidade dentro do âmbito militar continua sendo um tema tabu. Embora os homossexuais tenham sempre prestado serviço militar, não o fizeram abertamente enquanto tal (CARREIRAS, 2004, p. 68). A polêmica que envolve a temática dificulta tratar abertamente sobre o a questáo da diversidade sexual e o fim de obstáculos que impedem a integração de militares homossexuais sem discriminações dentro das Forças Armadas Brasileiras. Uma mudança de paradigma, e a formação de um ambiente favorável à integração de militares homossexuais passa pela desconstrução de valores heteronormativos excludentes, enraizados em padróes socioculturais, político-históricos, que implementaram a superioridade de uma orientação: a heterossexual (TEIXEIRA, 2012, p. 504), sobre as demais (SILVA; ORNAT, 2017, p. 424).

Como alternativa aos problemas relatados no caso das Forças Armadas Brasileiras, diversos países vêm implementando uma postura integracionista, como por exemplo: Canadá, Espanha, Israel, Argentina, Reino Unido, Holanda, adotando um posicionamento de aceitaçáo da diversidade sexual, tendo em vista que essa diversidade não impede a realização de qualquer tipo de atividade militar, não sendo, portanto, um fator que desabone o perfil militar, assim como não constitui um risco para a harmonia, hierarquia e disciplina militar (VERBICARO SOARES, 2015, p. 552). 
Assim, a Força Aérea do Brasil (FORÇA AÉREA BRASILEIRA, 2018), do mesmo modo que a Marinha (MARINHA DO BRASIL, 2018) e o Exército (EXÉRCITO BRASILEIRO, 2018) carecem de eliminar as condutas e obstáculos discriminatórios, que humilham e constrangem (FIGUEIREDO, 2008, p. 63), além de que impedir a integração de militares por questôes de orientação sexual ou identidade de gênero, porquanto, o acatamento à disciplina e hierarquia nas Instituiçôes Militares não passa por temas de diversidade sexual ou de gênero (D' ARAUJO, 2019). Como visto, essas questóes náo constituem dificuldades para atividade militar e, também, não atacam a honra, o conjunto de regras, a disciplina ou hierarquia militares (DUAILIBI, 2016).

Após onze anos do caso Laci de Araújo, pouco foi feito para permitir a criação de um ambiente militar harmônico e integrador. Com as palavras do próprio Laci: "a repressão existe e é uma determinação dos comandos para policiais e agentes homossexuais serem expurgados com uma série de procedimentos administrativos falseados nos quais o pano de fundo, na realidade, é o preconceito (UOL, 2018).

É importante enfatizar que a orientaçấo homossexual segue sendo compreendida socialmente no Brasil como uma problemática relacionada à moral, como um pecado ou uma doença a ser curada (VERBICARO SOARES, 2016, p. 57). Destarte, a condenação da diversidade sexual ainda norteia os argumentos contrários à essa aceitaçáo, pois perpetuam o entendimento de que a aceitação da homossexualidade implicaria no risco aos padróes naturais e heterossexuais dominantes (VERBICARO SOARES; CRUZ, 2018, p. 304). Isso corrobora para a raiz do problema da homossexualidade nas Forças Armadas, que seria a estigmatizaçáo por parte de heterossexuais contra homossexuais, sendo mais conveniente banir o indivíduo homossexual a combater o preconceito (ROCHA, 2011).

$\mathrm{Na}$ esfera militar, os argumentos contrários atestam uma suposta ameaça a coesão das unidades militares com a permanência de um integrante militar homossexual (CARREIRAS, 2004, p. 70) e, pior, que a integraçáo de uma pessoa homossexual seria um perigo para a integridade física ou moral dos integrantes das Forças Armadas, estigmatizando os homossexuais como pessoas promíscuas e que não seriam capazes de controlar a libido e seus impulsos sexuais (VERBICARO SOARES, 2015, p. 678).

Contra essa realidade hostil para a aceitação de militares homossexuais, destacase a necessidade de criação de medidas positivas, dentro da Administração Pública, acatando os princípios da igualdade e de não discriminaçáo, para que se possam abranger as finalidades de igualdade formal e legal (BUSTOS, 2010, p. 237), ou seja, na implementação de medidas no espaço das Forças Militares, num cenário público de defesa da dignidade humana, respeito à diversidade sexual e de gênero, de igualdade e não discriminação (VERBICARO SOARES, 2018, p. 263). 


\section{Constituição de 1988: a transiçáo entre a ditadura militar e a democracia}

Para aprofundar o raciocínio aqui explorado, é preciso entender que a hostilidade à condição homossexual entranhada nas forças armadas é fruto de uma sociedade que, sob diversos pretextos, tenta, continuamente, suprimir o manifesto por direitos de pessoas homossexuais.

Fazendo uma retrospectiva aos anos 1980, quando ocorreu o processo de redemocratização do Brasil, que vivia em uma Ditadura Militar (CODATO, 2005), houve a oportunidade de pronunciamento de diversas minorias sociais, dentre as quais as pessoas homossexuais, em busca de direitos a serem garantidos pela nova Constituição (SANTOS; MELO, 2018, p. 82-83).

No entanto, a luta por direitos se esbarrava nos legisladores, que, baseados em manter a "moral e os bons costumes", se contrapunham aos interesses da populaçáo homossexual. Somado a isso, havia a opinião pública alimentada pelo surto de AIDS Síndrome da Imunodeficiência Adquirida, que acometia predominantemente a população homossexual, entendido por fundamentalistas religiosos como uma consequência do pecado da homossexualidade. Nesse contexto, parlamentares se opuseram à inclusão do termo "orientação sexual" na constituinte, sob diversos argumentos baseados em uma moral evangélica. (SANTOS; MELO, 2018, p. 83-84).

Além disso, vale ressaltar que o texto original da Carta Magna não prevê famílias constituídas por lésbicas, gays, bissexuais, travestis, transexuais e intersexuais, trazendo, pouco se empenhando em trazer maior inclusão em relação à diversidade de orientação sexual.

O texto constitucional, no artigo 226, parágrafo terceiro, diz: "Para efeito da proteção do Estado, é reconhecida a união estável entre o homem e a mulher como entidade familiar, devendo a lei facilitar sua conversão em casamento". De modo literal, não se poderia reconhecer união estável entre dois homens ou duas mulheres, sem contrariar a Constituição. Entretanto, o STF (STF, 2011) passou a reconhecer a união homoafetiva:

$\mathrm{O}$ ministro Ayres Britto argumentou que o artigo $3^{\circ}$, inciso IV, da $\mathrm{CF}$ veda qualquer discriminação em virtude de sexo, raça, cor e que, nesse sentido, ninguém pode ser diminuído ou discriminado em função de sua preferência sexual. "O sexo das pessoas, salvo disposição contrária, não se presta para desigualaçáo jurídica”, observou o ministro, para concluir que qualquer depreciação da união estável homoafetiva colide, portanto, com o inciso IV do artigo $3^{\circ} \mathrm{da}$ CF.

Este retorno ao passado pode ajudar a compreender o pensamento discriminatório no interior das Forças Armadas Brasileiras, uma vez que isso é fruto de uma sociedade historicamente homofóbica (VERBICARO SOARES, 2019, p. 155-6), e que se fundamenta em uma moral religiosa, ao mesmo tempo que se diz ser um Estado laico. 


\section{A orientação homossexual plasmada na experiência internacional das Forças Armadas}

Essa parte do estudo teve como objetivo expor o entendimento sobre a orientaçáo homossexual nas experiências de outros países. A problemática que envolve a questão, fez com que determinados países adotassem posturas diversificadas quanto a adoção ou negação de medidas que facilitassem ou impedissem a incorporação de militares homossexuais em certas instituições militarizadas pelo mundo. Dessa maneira, por exemplo, expressando condutas de proibição estariam países como Turquia, Grécia e outros: "o mesmo acontece na Turquia, Grécia e Itália. Segundo dados relativos a 1999, em todos estes países a declaração de homossexualidade é legalmente condição para a exclusão do serviço militar”. (CARREIRAS, 2004, p. 71).

Tema polêmico, muitos Estados concebem-na como incompatível com a profissão das Armas, alijando o cidadão das fileiras do Exército, Marinha e Aeronáutica por quebra de decoro da classe e da dignidade castrense. Punida criminalmente em alguns países, a questão é tratada de forma estigmatizante e restritiva, sob a égide de uma ordem jurídica carente de neutralidade. Isto porque, afastar alguém das fileiras das Forças Armadas em virtude de sua orientação sexual é promover o discurso do ódio, quando é dever do Estado coibi-lo (ROCHA, 2011).

No caso Laci de Araújo, levado à mídia em junho 2008 (ÉPOCA, 2017), Laci e seu parceiro Fernando Alcântara de Figueiredo decidiram manter o relacionamento em segredo, já que ambos eram oficiais do exército e a carreira militar era, e ainda é, permeada por preconceitos.

Depois que levaram a história aos meios de comunicação, Laci Araújo e Fernando Alcântara foram presos e acusados de comportamento antiético. À época da prisão, eles afirmam que foram torturados, perseguidos e que sofreram discriminação por orientação sexual. Araújo afirma que, em uma de suas prisóes, foi espancado e sufocado com saco plástico. A denúncia por corrupção nunca foi investigada pelo Exército, tanto Araci quanto Alcântara foram reformados e, hoje, o companheiro de Fernando, que tem problemas de saúde, recebe um valor simbólico das Forças Armadas, não tendo seu tratamento médico custeado. Nos processos internos, os dois foram considerados culpados pelo crime de difamação contra o Exército (FÓRUM, 2014).

No mesmo sentido, um país como os Estados Unidos, possui um histórico de discriminações com as pessoas homossexuais no âmbito das Forças Armadas Norteamericanas (VERBICARO SOARES, 2011, p. 155). Para corroborar esse entendimento, se pode citar o caso da sargento Jene Newsome - "A sargento Jene Newsome foi demitida da Força Aérea dos Estados Unidos por causa de sua orientação sexual” (ACAPA, 2010), que de um modo similar ao de Laci de Araújo, teve um desfecho, também, de demissão da militar do quadro de oficiais da Força Aérea americana, demonstrando uma postura intransigente com diversidade sexual e preceitos da Constituição dos Estados Unidos da 
América, em especial em relação à igualdade, não discriminação, liberdade e dignidade da pessoa humana entre outros.

Destaca-se nesse ínterim que o modelo discriminatório dos Estados Unidos era regido pela normativa do "não pergunte, não diga" que permaneceu vigorante nessas Instituiçóes Militares desde o ano de 1993 (FORTUNE, 2018). Essa política foi modificada pelo ex-presidente Barack Obama no ano de 2010. Em contraponto com a realidade do caso brasileiro de Laci de Araújo, as discussões sobre a aceitação/negação de integrantes militares em servir às Forças Armadas, continuam em pleno século XXI. Nesse sentido, é imprescindível recordar que a experiência de 2008, quando o ex-Sargento Laci de Araújo, ao assumir sua relaçáo homoafetiva com um companheiro militar (Fernando Alcântara de Figueiredo) em entrevista à revista brasileira ÉPOCA, gerou uma discussão polêmica sobre a homossexualidade no âmbito militar no Brasil (CONJUR, 2008). Em 2009, o casal criou uma ONG para ajudar militares que enfrentam problemas por conta de sua orientação homossexual.

Também, em outro caso polêmico relacionado à militares homossexuais no país, o caso de Osvaldo Brandão Sayd e outro militar (tenente-coronel), teria sido supostamente aposentado precocemente pelo Superior Tribunal Militar por ter mantido relaçóes sexuais com um subordinado (O GLOBO, 2010). Neste outro episódio polêmico, a condenação do militar teria sido justificada por: "ferir o decoro militar e de "denegrir" as Forças Armadas. Segundo o relator do caso, o ministro José Américo, a condenação não se deve à orientação sexual do militar, mas pune os 'excessos' incompatíveis com a função do oficial" (UOL, 2010). Esses dois casos (Laci de Araújo e Osvaldo Sayd) foram apenas os que tiveram maior repercussão na mídia brasileira, mas que geram uma indagação: se em apenas dois casos os resultados foram semelhantes com o afastamento dos militares, quantos outros, que não foram revelados poderiam ter seguido a mesma postura de desligamento do quadro de militares das Forças Armadas Brasileiras?

O caso de Laci de Araújo, após 11 (onze) anos, teve uma mudança repentina desde a primeira entrevista com a Revista ÉPOCA, passando pela aposentadoria parcial dos mesmos do Exército Brasileiro, até a criação de um instituto (Ser de Direitos Humanos e da Natureza) que trabalha com episódios semelhantes de preconceito e discriminaçáo (BRITO FILHO, 2005, p. 228) na esfera militar (ÉPOCA, 2017).

Contrária a essas situações de preconceito e discriminação, países com experiência de aceitação/integração de militares homossexuais demonstram que a orientaçáo sexual não deve ser entendida como um impedimento para a realizaçáo de qualquer tipo de atividade, mesmo dentro do serviço militar. Com esse entendimento, pioneiros são os países: Espanha, Reino Unido, Canadá, Dinamarca, Holanda, Alemanha e República Checa que incitam a conscientização sobre a diversidade sexual e, em destaque, o respeito à dignidade humana, à sexualidade e aos Direitos Humanos (VERBICARO SOARES, 
2011, p. 159). Assim: “a Holanda, o país mais tolerante a este propósito. Mas também a Noruega, Dinamarca e Canadá adotam uma política de total abertura. Na Noruega e na Dinamarca a assunção da homossexualidade não pode servir de base para a isenção do serviço militar" (CARREIRAS, 2004, p. 71).

Essas posturas para a aceitaçáo da diversidade sexual dentro das instituiçóes militares permitem responder a seguinte pergunta do estudo: $O$ fato de um militar ser homossexual implica em um empecilho para desenvolver o trabalho militar? A resposta foi negativa, devido à já incorporação de militares homossexuais ou bissexuais em Forças Armadas de distintos países que comprovam que a orientação sexual não influi no desempenho ou realização da atividade militar.

Corroborando com essa postura de integração da diversidade sexual dentro do espaço militar, experiências também no Reino Unido indicam a possibilidade de aceitação sem prejuízos para a organização. Nesse aspecto, se pode citar o caso de Lance Corporal James Wharton, que integra a "Household Cavalry", grupo das Forças Armadas britânicas que tem o objetivo de oferecer segurança a líderes de Estado em visita ao país e a oficiais de alta patente (UOL, 2010). De acordo com esse episódio, o oficial militar contraiu matrimônio com seu companheiro afetivo, contando com a participação na cerimônia de seus companheiros militares e a aprovação dos mesmos, o que demonstra que a orientação de alguém não pode ser usada como justificativa para o exercício de um trabalho ou na realização das práticas cotidianas na vida pessoal. Neste sentido, Batalha (2013) aborda que:

Acredita-se que a discriminação operada contra homossexuais no mercado de trabalho, deve-se à arraigada mentalidade heterossexista e homofóbica dos tomadores de serviços, uma vez que não há dados que comprovem que a homossexualidade tenha influência na produtividade e na capacidade profissional.

$\mathrm{Na}$ Espanha também se encontram episódio similares de casamento, onde a orientação homossexual não foi um problema para a aceitação de um militar homossexual. Nesse sentido, o caso do Tenente Coronel, José María Sánchez Silva, resolveu expor à sociedade sua orientação do desejo homossexual através de uma entrevista à revista Zero, revista essa que é conhecida nesse país como pertencente à comunidade homossexual (VERBICARO SOARES, 2015, p. 532): "No ano de 2006, período em que se legalizou o matrimônio homossexual, o casal de militares com orientação do desejo homossexual, que pertenciam ao quadro do exército de ar (se casaram na Prefeitura da capital andaluza”, constituindo, portanto, como o primeiro casamento homossexual nas Forças Armadas da Espanha no Século XX (VERBICARO SOARES, 2011, p. 161-2).

Em continuidade com o ideal de aceitação da diversidade sexual dentro das Forças Armadas dos países supracitados, o Canadá não faz distinção sobre a orientação sexual de uma integrante militar, mas exige que os seus militares respeitem o controle das normativas que versam sobre a honra, a disciplina e a hierarquia presente nas Instituiçóes 
Militares pelo país. Nesse aspecto, a interação das Organização de Defesa em redes sociais, por exemplo, no site oficial das Forças Armadas Canadense no sentido de não realizar discriminação com uma determinada orientação sexual. (AGENCIA EFE, 2017).

Essa iniciativa canadense permite a explicitação de posicionamentos que permitem à diversidade sexual, uma condição de respeito e integração, sem sofrer preconceito e discriminaçáo no desenvolvimento da atividade militar, demonstrando que uma orientação sexual, no caso do estudo, a homossexual, não possui justificativas possíveis que impeçam a realização de qualquer tipo de atividade militar.

\section{Os problemas para a aceitaçáo da orientação homossexual dentro das Forças Armadas Brasileiras}

No sentido de visibilizar a problemática da orientação homossexual dentro da esfera militar, se fez necessária a especificaçáo dessa parte do estudo, justamente para elucidar a sociedade de que a homossexualidade não representa um impedimento para a realização de qualquer tipo de atividade pertencente ao serviço militar. Portanto, não pode ser atestada como uma limitaçáo ou doença que incapacite uma pessoa do exercício militar.

Para corroborar que a visão de que essa orientação sexual não representa uma doença, Olavarría (2004, p. 79) argumenta que: "ela náo corresponde nem a uma enfermidade, não é perversão, nem algo raro que se deva suspeitar”. Destarte, a orientação sexual não possui fundamentação plausível que comprove alguma situação que incapacite uma pessoa em realizar um trabalho dentro do âmbito militar e, até mesmo, fora dele.

Assim, o estudo buscou responder outra das indagaçóes iniciais: como é vista a homossexualidade dentro do espaço das Forças Armadas Brasileiras? A resposta persiste na existência de posturas preconceituosas e discriminatória que continuam a fomentar uma prática de rechaço e dificuldades para a aceitação/integração de militares assumidamente homossexuais dentro das Instituiçóes de Defesa do Brasil. Por outro lado, o Século XXI traz também mudanças sobre a sensibilização da sociedade brasileira para temas que envolvem a sexualidade humana. Cada vez mais se visibiliza a questão da diversidade sexual e a necessidade de respeito à dignidade da pessoa humana, fatos que permitem considerar que, condutas discriminatórias quanto à orientação homossexual e obstáculos existentes que dificultam a integração dessas pessoas, possam ser diminuídos ou, até mesmo, eximidos em favor da real incorporação de pessoas homossexuais como militares.

A incorporação de mulheres e homossexuais às Forças Armadas só pode ser devidamente considerada quando as sociedades estabelecem para si que, liberdade de escolha e direitos iguais para todos, são parte inviolável da soberania individual, ou seja, quando os princípios de igualdade e democracia se tornarem a gramática da política. (D’ARAÚJO, 2003) 
Os desafios são muitos, mas é necessário o esforço conjunto de toda a sociedade brasileira em viabilizar quebra de paradigmas que implemente o acesso aos mesmos direitos e de não ser discriminado baseado na orientação sexual de uma pessoa no exercício de qualquer profissão. Infelizmente, o fato de um militar se assumir como homossexual ainda constitui uma característica considerada por outros colegas militares como prejudicial, mas os posicionamentos que defendem essa negação são contraditórios e não se fundamentam, apenas repetem um discurso discriminatório cultural e religioso, perpetuado ao longo de séculos.

É importante destacar que esse processo histórico tem como fundo, de acordo com França (2016), que:

Ser militar e ser homem são atributos que se desenvolveram de maneira indissociável, de modo que a cultura militarista sempre procurou coibir o desejo atrelado às sexualidades indefinidas, às perversóes, às imoralidades, à pederastia. $\mathrm{O}$ padrão classificatório imposto pela modernidade não permite ir contra os desígnios divinos e sua honrosa celebração à monogamia heterossexual, única possibilidade capaz de gerar descendentes e os futuros "filhos da pátria".

Suas argumentações são frágeis e se desconstituem quando se contrapóem às experiências de outros países que resolveram adotar uma postura de aceitação da orientação homossexual, por acreditar e comprovar, que ela não diminui ou prejudica o serviço militar realizado por uma pessoa homossexual. Dessa forma, reafirma-se que o argumento de que um militar representaria uma ameaça às Forças Armadas no Brasil não pode prosperar, pois ter uma pessoa homossexual desempenhando o exercício da atividade militar não implicaria na quebra da convivência harmoniosa do quadro de militares, muito menos gerando problemas para a ordem, honra, moral, disciplina e hierarquia das Organizações de Defesa do país.

Com esse entendimento, válidas são as palavras de Sánchez (2006, p. 36): "as falsas crenças e preconceitos estão enraizados em pensamentos como os homossexuais não são pessoas trabalhadoras". Como explicitado, essa argumentação é falha e não condiz com a realidade. Outro exemplo de argumentação discriminatória pode ser encontrado a seguir:

Com mais esse caminho em direção à liberdade sexual dentro das Forças Armadas, seria obrigatória as brigas com o serviço militar obrigatório. Nenhum pai estaria tranquilo em saber que seu filho, durante cinco dias de acampamento, estaria dormindo em uma cabana com um companheiro homossexual sem reclamar, pois, se o faz, receberia uma punição por discriminação sexual (PEREIRA, 2019).

No mesmo sentido em que: "quando começo a servir na marinha, o homossexualismo não era permitido, agora que se tornou algo tolerável, me mandei antes que seja obrigatório!” (PEREIRA, 2019). Essas afirmaçóes chamam a atenção para a existência de açóes que discriminam pessoas pelo fato de possuírem uma orientação sexual simplesmente diversa da heterossexual dominante, fato que não deveria existir uma 
vez que não se deve atribuir maior ou menor importância dentro da diversidade sexual existente, visto que todas são dignas de respeito e deveriam ser tratadas em igualdade, no entanto:

A sociedade que se proclama defensora da igualdade é a mesma que ainda mantém uma posição discriminatória nas questôes da sexualidade. Nítida é a rejeição social à livre orientação sexual. A homossexualidade existe e sempre existiu, mas é marcada por um estigma social, sendo renegada à marginalidade por se afastar dos padróes de comportamento convencional (DIAS, 2010).

De acordo com essa igualdade comentada, sendo "o princípio mais reiteradamente invocado na nossa Carta Magna” (DIAS, 2010), a própria Carta Magna assegura o exercício dos direitos sociais e individuais, de liberdade, segurança, de bem-estar, de desenvolvimento, de igualdade e o da justiça como valores supremos de uma sociedade fraterna, pluralista e sem preconceitos. É o destino fundamental do Estado democrático e de um ideal republicano (PLANALTO, 2018). Mas essa igualdade é ameaçada quando preceito normativo vigente no Ordenamento Jurídico Militar estigmatiza e discrimina a orientação homossexual (VERBICARO SOARES, 2011, p. 154), quando permite, por exemplo, a caracterização de conduta típica e antijurídica, portanto, que diverge da lei, considerando o ato homossexual ilegal, de acordo com dispositivo do CPM praticar ato libidinoso com características homossexuais. Essa equiparação discrimina os homossexuais e fere a dignidade da pessoa humana, a diversidade sexual e os Direitos Humanos.

\section{$6 \mathrm{O}$ artigo 235 do CPM - Código Penal Militar}

De acordo com a efetiva previsão do artigo 235 do CPM: praticar a homossexualidade, ou seja, atos libidinosos de característica homossexual, permite a punição de acordo com essa normativa. Dessa maneira, se responderá a última pergunta do estudo: Ser homossexual é proibido por alguma normativa das Forças Armadas Brasileiras?

A normativa em vigor possui uma especificação relacionada à homossexualidade, que não é vislumbrada em relação às demais existentes, ou seja, o fato de informar expressamente essa orientação sexual como proibida, repercute na formação de uma ideia discriminatória para a homossexualidade. O legislador, ao criar a previsão legal, mencionando o ato libidinosos de forma abrangente, não deveria explicitar a palavra 'homossexual' como foi feito, pois cria uma interpretaçáo taxativa e excludente da orientação homossexual, como se ela fosse a mais grave e digna de sofrer algum tipo de repressão. Nesse sentido, a normativa apenas estigmatizou a homossexualidade de forma desnecessária, considerando que "a permanência da dicção pederastia só irá ajudar na 
promoção de um preconceito mais acentuado em relação aos homossexuais que ainda sofrem discriminação" (PORTELA, 2013).

O artigo 235 do Código Penal Militar, originário de 1969, informa que:

Praticar, ou permitir o militar que com ele se pratique ato libidinoso, homossexual ou não, em lugar sujeito a administração". Ou seja, o militar não pode praticar o tal "ato libidinoso" e não pode aceitar nenhum comportamento deste tipo vindo de um colega. Quem desobedecer à lei está sujeito a pena de seis meses a um ano de prisão (PLANALTO, 2018).

Em 2010, no caso de Osvaldo Sayd, o Superior Tribunal Militar atribuiu a depreciação da dignidade e o decoro da "classe" ao fato de o Oficial ter tido relacionamento com subordinado, mesmo tendo ocorrido fora da área de administração militar, enfatizando-se o fato de o relacionamento ser homoafetivo, o que na visão daquele Tribunal, foi a causa de um desequilíbrio na entidade militar:

[...] Embora tal relacionamento homoafetivo tenha ocorrido em lugar não sujeito à Administraçáo Militar, consubstanciou um proceder incompatível com a dignidade e o decoro de classe, uma vez que provocou descrédito de sua autoridade frente aos comandados, que passaram a dispensar-lhe tratamento jocoso e depreciativo, em decorrência da promiscuidade que se instalou entre os círculos hierárquicos. [...] Acórdão Num: 0000006-39.2008.7.00.000. (STM, 2010).

Como alternativas ao problema relatado sobre essa tipificação discriminatória, existem dois projetos de leis, decorrentes de esforços da Comissão de Relaçóes Exteriores e Justiça e de Cidadania, que buscam, justamente, adequar às previsóes dos Códigos Penal e de Processo Penal Militares às realidades da sociedade brasileira e aos preceitos constitucionais da República Federativa do Brasil, com o objetivo de sanar as orientaçóes que propiciem discriminaçóes (STM, 2018): “O PL 9432/2017 traz importantes reformas no Código Penal Militar, alterando dezenas de dispositivos do Decreto-Lei 1.001/1969 e o art.1 da Lei 8.072/90” (CÂMARA DOS DEPUTADOS, 2019) e “Já o PL 9436/2017 altera trechos do CPPM (Decreto-lei no 1.002/69), assim como revoga o artigo 90-A da Lei no 9.099/95" (CÂMARA DOS DEPUTADOS, 2019).

Instrumentos legislativos em 2019 tiveram reviravoltas, pois, no início do ano, a Mesa Diretora da Câmara dos Deputados arquivou os projetos referidos. Seguidamente, no mês de abril do referente ano, no Plenário da Câmara foi apresentado requerimento de desarquivamento: "Proposiçóes n. 1310/2019, pela Comissão de Relaçóes Exteriores e de Defesa Nacional, que: "Requer, nos termos do artigo 105, parágrafo único, do Regimento Interno, o desarquivamento dos Projetos de Lei nos 9.432 e 9.436, de 2017” (CÂMARA DOS DEPUTADOS, 2019). Frente a essas contínuas modificações, dentre as propostas de alteraçóes às normas militares está a de modificação do artigo 235 do CPM, com a devida supressão da palavra homossexual da tipificação condenatória, fruto de incessante polêmica nas últimas décadas na sociedade brasileira. 


\section{Consideraçóes finais}

Depois dos 11 anos do caso Laci de Araújo de 2008, os questionamentos sociais sobre a aceitação e negação de militares homossexuais nas Forças Armadas Brasileiras seguem presentes. Para algumas argumentaçóes em favor da integração dessas pessoas como militares, essa orientaçáo náo deveria ser considerada como motivo de limitar o desenvolvimento de qualquer atividade, seja dentro do serviço militar ou fora dele. Com essas premissas, existe uma postura em considerar a orientaçáo homossexual como uma a mais pertencente à diversidade sexual, digna de respeito e consideração, como já ocorre com a heterossexual.

Essa orientação pela integração da diversidade sexual e respeito aos Direitos Humanos reconhece a importância de preservação da dignidade humana e o pleno desenvolvimento da sexualidade, sem sofrer preconceitos e discriminaçóes que impeçam que pessoas homossexuais possam desempenhar qualquer tipo de atividade laboral/ profissional.

De modo diverso, o estudo apontou a existência de argumentos contrários à aceitação de militares homossexuais, em geral, relacionados à posicionamentos sem base científica, baseados em um tradicionalismo histórico/religioso heteronormativo, que atribuiu uma visão estereotipada sobre a orientação homossexual e sua suposta inviabilidade no exercício da atividade militar por parte de uma pessoa homossexual. De acordo como essa argumentação negativa, a incorporação de um militar homossexual poderia gerar um risco à moral, à honra, à disciplina, e à hierarquia das Instituiçóes Militares.

Para essa vertente, o estudo concluiu que essas premissas são frágeis e não possuem bases que atestem seus discursos. O estudo também evidenciou a experiência de diversos casos em que as Forças Armadas de diferentes países adotaram políticas de integração da diversidade sexual para atrair um maior número de militares comprometidos com os seus países e com o serviço militar, náo importando a orientaçáo sexual dos mesmos e sim o comprometimento e a vontade de servir na defesa desses países. Destarte, a aceitação de militares homossexuais vem se apresentando uma importante medida para a formação de ambientes mais saudáveis para as sociedades que adotam essa integração, seja no aspecto das Forças Armadas ou na incorporação em diversas atividades laborais, onde a orientação sexual de uma pessoa náo define a qualidade da atividade profissional.

As evidências internacionais auxiliam na formação de uma diretriz a ser aprendida também pela sociedade brasileira, em destaque no tema de diversidade sexual e integração de grupos em situação de exclusão social, como os dos homossexuais no Brasil. Espera-se que na próxima década, o caso de Laci de Araújo e outros sejam lembrados apenas, como um momento histórico em que a orientaçáo sexual de uma pessoa era usada como empecilho 
para o serviço militar, mas que a futura realidade esteja na incorporação de militares, baseada nas qualidades vocacionais de cada um, sem restringir suas participaçóes por motivos de discriminação por uma orientação sexual diversa da heterossexual dominante.

\section{Referências}

ACAPA. 2010. Sargento é demitida da Força Aérea por ser lésbica. Disponível em: https://acapa.com.br/sargento-e-demitida-da-forca-aerea-por-ser-lesbica/. Acesso em: 05 de jul. 2019.

AGENCIA EFE. 2017. Canadá responde Trump convidando transexuais a se alistarem em seu Exército. Disponível em: https://www.efe.com/efe/brasil/mundo/canada-respondetrump-convidando-transexuais-ase-alistarem-em-seu-exercito/50000243-3337084. Acesso em: 10 de jul. 2019.

BATALHA, Glaucia Fernanda Oliveira Martins. 2013. Orientação sexual e discriminação no ambiente laboral. Disponível em: https://www.publicacoesacademicas. uniceub.br/rdi/article/view/2716/pdf Acesso em: 23 de ago. 2019.

BBC BRASIL. 2018. Bolsonaro presidente: General Mourão diz que temor pelo futuro da democracia é 'choro de perdedores'. Disponível em: https://www.bbc.com/portuguese/ brasil-46027695. Acesso em: 4 de jul. 2019.

BRITO FILHO. José Claudio. Direitos Fundamentais \& Relaçóes Sociais no Mundo Contemporâneo. Direitos Humanos e Discriminação no Brasil. Curitiba, Brasil: Editora Juruá, 2005.

BUSTOS, María Ángeles. "La transcendencia del sistema de función pública en el desarrollo de la igualdad”. In: RUIZ, Manuela Mora. (Dir.) Formación y objeto del Derecho antidiscriminatorio de género: perspectiva sistemática de la igualdad desde el Derecho público. Barcelona, Espanha: Atelier, pp. 235-54, 2010.

CÂMARA DOS DEPUTADOS. 2019. PL 9432/2017. Disponível em: http://www. camara.gov.br/proposicoesWeb/fichadetramitacao?idProposicao=2166877. Acesso em: 11 de jul. 2019.

CÂMARA DOS DEPUTADOS. 2019. PL 9432/2017. Disponível em: https://www. camara.leg.br/proposicoesWeb/fichadetramitacao?idProposicao=2166877. Acesso em: 12 de jul. 2019.

CÂMARA DOS DEPUTADOS. 2019. PL 9436/2017. Disponível em: http://www. camara.gov.br/proposicoesWeb/fichadetramitacao?idProposicao=216688. Acesso em: 11de jul. 2019. 
CÂMARA DOS DEPUTADOS. 2019. PL 9436/2017. Disponível em: https://www. camara.leg.br/proposicoes Web/fichadetramitacao?idProposicao=2166882. Acesso em: 12 de jul. 2019.

CARREIRAS, Helena. "Diversidade Social nas Forças Armadas: Gênero e Orientação Sexual em Perspectiva Comparada”. In.: Revista Nação e Defesa. Lisboa, Portugal. N. o $107-2 .^{\text {a }}$ Série, pp. 61-88, 2004.

CEZÁRIO, Joelma; KOTLINSKI, Kelly; NAVARRO, Melissa. Legislação e Jurisprudência LGBTTT. Brasília, Brasil: Instituto de Bioética, Direitos Humanos e Gênero e Associação Lésbica Feminista de Brasília Coturno de Vênus, 2007.

CODATO, Adriano Nervo. Uma história politica da transição brasileira: da ditadura militar à democracia. Disponível em: http://www.scielo.br/scielo.php?script=sci_ serial\&pid=0104-4478\&lng=pt\&nrm=iso. Acesso em: 29 de fev. 2020.

CONJUR, 2008. Sargento gay é condenado a seis meses de prisão por deserção. Disponível em: https://www.conjur.com.br/2008-set-26/sargento_gay_condenado_seis_meses_ prisao. Acesso em: 10 de jun. 2019.

D' ARAÚJO. Maria Celina. 2003. Mulheres, homossexuais e Forças Armadas no Brasil. Disponível em: https:/www.migalhas.com.br/arquivo_artigo/art20080618-1.pdf. Acesso em: 27 de ago. 2019.

D’ ARAUJO. Maria Celina. Pós-modernidade, sexo e gênero nas Forças Armadas.

DEFESA. 2019. Forças Armadas e Estado-Maior Conjunto. Disponível em: https://www. defesa.gov.br/forcas-armadas. Acesso em: 05 de jul. 2019.

DIAS, Maria Berenice. 2010. A Igualdade Desigual. Disponível em: http://www. mariaberenice.com.br/manager/arq/(cod2_646)32__a_igualdade_desigual.pdf Acesso em: 22 de ago. 2019.

Disponível em: https:/www.resdal.org/producciones-miembros/redes-03-daraujo.pdf. Acesso em: 04 de jun. 2019.

DUAILIBI, Roberto. A essência do militar. Disponível em: http://www.eb.mil.br/ documents/10138/7948276/A+Ess\%C3\%AAncia+do+Militar.pdf/5ec48fee-ec314dbc-9f3a-78dd3dd8f0f5. Acesso em: 03 de jul. 2019.

ÉPOCA. 2017. O que aconteceu com o primeiro casal gay a se revelar no Exército brasileiro. Disponível em: https://epoca.globo.com/especiais/EPOCA-1000/ noticia/2017/08/o-que-aconteceu-com-o-primeiro-casal-gay-se-revelar-no-exercitobrasileiro.html. Acesso em: 09 de jul. 2019.

EXÉRCITO BRASILEIRO. 2018. Missão e visão de futuro. Disponível em: http://www. eb.mil.br/missao-e-visao-de-futuro. Acesso em: 04 de jul. 2019. 
FIGUEIREDO. Fernando. Soldados não choram: a vida de um casal homossexual no Exército do Brasil. Depoimento a Roldão Arruda. São Paulo. Brasil: Editora Globo, 2008.

FORÇA AÉREA BRASILEIRA. 2018. Missão, visão e valores. Disponível em: http:// www.fab.mil.br/missaovisaovalores. Acesso em 04 de jul. 2019.

FORTUNE. 2018. 'Don't Ask, Don't Tell'Was Announced by Bill Clinton 25 Years Ago. Disponível em: http://fortune.com/2018/07/19/dont-ask-dont-tell-25-anniversary/. Acesso em: 05 de jul. 2019.

FÓRUM. 2014. "Nosso objetivo é a extinção da Justiça Militar", diz ex-sargento homossexual discriminado. Disponível em: https://revistaforum.com.br/noticias/o-nossoobjetivo-e-extincao-da-justica-militar-diz-ex-sargento-perseguido-por-ser-homossexual/. Acesso em: 09 de jul. 2019.

FRANÇA, Fábio Gomes. 2016. "Hierarquia da invisibilidade": preconceito e homofobia na formação policial militar. Disponível em: http://revista.forumseguranca.org.br/index. php/rbsp/article/view/700/244 Acesso em: 23 de ago. 2019.

GAZETA DO POVO. 2010. Tropa não obedece militar homossexual, diz general no Senado. Disponível em: https://www.gazetadopovo.com.br/vida-e-cidadania/tropa-naoobedece-militar-homossexual-diz-general-no-senado-ax824y9w0kbdloyyyespu9kr2/. Acesso em: 13 de jun. 2019.

JANOWITZ, Morris. El soldado profesional. Madrid, España: Ministerio de Defensa, 1990.

LIONÇO, Tatiana. "Que Direito à Saúde para a População GLBT? Considerando Direitos Humanos, Sexuais e Reprodutivos em Busca da Integralidade e da Eqüidade”. In.: Revista Saúde e Sociedade. São Paulo, Brasil. V.17, n.2, pp.11-21, 2008.

MARINHA DO BRASIL. 2018. Missão e visão de futuro da Marinha. Disponível em: https:/www.marinha.mil.br/content/missao-e-visao-de-futuro-da-marinha. Acesso em: 03 de jul. 2019.

O GLOBO. 2010. Senado aprova indicação de Raymundo Nonato, general que criticou gays nas Forças Armadas. Disponível em: https://oglobo.globo.com/politica/senadoaprova-indicacao-de-raymundo-nonato-general-que-criticou-gays-nas-forcas-armadaspara-3041457. Acesso em: 04 de jul. 2019.

O GLOBO. 2010. STM exclui e aposenta militar gay das Forças Armadas. Disponível em: https://oglobo.globo.com/politica/stm-exclui-aposenta-militar-gay-das-forcasarmadas-3041162. Acesso em: 10 de jul. 2019.

OLAVARRÍA, José. Adolescentes: Conversando La intimidad. Vida cotidiana, sexualidad y masculinidad. Santiago de Chile. Chile: FLACSO-Chile, 2004. 
PEREIRA. Carlos Frederico. Homossexuais nas forças armadas: tabu ou indisciplina? Disponível em: http://campus.fortunecity.com/clemson/493/jus/m06-021.htm. Acesso em: 10 de jul. 2019.

PLANALTO. 2018. CONSTITUIÇÃO DA REPÚBLICA FEDERATIVA DO BRASIL $D E$ 1988. Disponível em: http://www.planalto.gov.br/ccivil_03/Constituicao/ Constituicao.htm. Acesso em 11 de jul. 2019.

PLANALTO. 2018. DECRETO-LEI No 1.001, DE 21 DE OUTUBRO DE 1969. Disponível em: http://www.planalto.gov.br/CCIVIL_03/Decreto-Lei/Del1001.htm. Acesso em 11 de jul. 2019.

PORTELA, Izaac da Silva. 2013. A controvertida previsão do termo "Pederastia" no Código Penal Militar. Faculdade Maurício de Nassau. Disponível em: http://jusmilitaris. com.br/sistema/arquivos/doutrinas/artigo_izaac.pdf Acesso em: 22 de ago. 2019.

ROCHA, Maria Elizabeth Guimarães Teixeira. 2011. Iguais, mas separados. Os homossexuais e as forças armadas. Disponível em: http://www.esdc.com.br/RBDC/ RBDC-17/RBDC-17-139-Artigo_Maria_Elizabeth_Guimaraes_Teixeira_Rocha_ (Iguais_mas_separados_Os_Homossexuais_e_as_Forcas_Armadas).pdf Acesso em: 22 de ago. 2019.

ROCHA, Maria Elizabeth. Iguais, mas separados. Os homossexuais e as forças armadas. In.: Revista Brasileira de Direito Constitucional. RBDC n. 17 - jan./jun. 2011.

SÁNCHEZ, Félix. Homosexualid y familia. Lo que los padres, madres, homosexuales y profesionales deben saber y hacer. Barcelona. España: Editorial GRAÓ, 2006.

SANTOS, Gustavo Gomes da Costa; MELO, Bruno Leonardo Ribeiro. The opposition to LGBT rights in the Brazilian national congress (1986-2018): actors, dynamics of action and recent developments. Disponível em: http://www.sbsociologia.com.br/sid/index.php/ sid/article/view/93/pdf_4. Acesso em: $20 \mathrm{de}$ fev. 2020.

SENADO FEDERAL. 2018. Atividade Legislativa. Art. 142. Disponível em: https:// www.senado.leg.br/atividade/const/con1988/con1988_atual/art_142_.asp. Acesso em: 06 de jun. 2019.

SILVA, Joseli Maria冈 ORNAT, Marcio Jose. Geografias Lésbicas: uma Entrevista com Eduarda Ferreira. In: Revista Latino Americana de Geografia e Gênero. Ponta Grossa, Brasil: Universidade Estadual de Ponta Grossa, v. 8, n. 1, pp. 424-434, 2017.

STF. 2011. Supremo reconhece união homoafetiva. Disponível em: http://www.stf.jus.br/ portal/cms/verNoticiaDetalhe.asp?idConteudo=178931. Acesso em: 03 de mar. 2020 .

STM. 2010. Acordão Num: 0000006-39.2008.7.00.0000 UF: DF. Disponível em: https://www2.stm.jus.br/pesquisa/acordao/2008/90/01.0002031/01.0002031.pdf Acesso em: 27 de ago. 2019. 
STM. 2018. Projetos de lei que modernizam os Códigos Penal Militar e de Processo Penal Militar avançam na Câmara. Disponível em: https://www.stm.jus.br/informacao/ agencia-de-noticias/item/8575-projetos-de-lei-que-modernizam-os-codigos-penalmilitar-e-de-processo-penal-militar-avancam-na-camara. Acesso em: 11 de jul. 2019.

TEIXEIRA, Flavia. "Histórias que não têm era uma vez: As (in) certezas da transexualidade”. In.: Revista Estudos Feministas, Florianópolis, Brasil, 20 (2): 256, maio-agosto, pp. 501- 12, 2012.

UOL. 2010. Militar de elite do Reino Unido casa-se com namorado. Disponível em: http://mixbrasil.uol.com.br/noticias/militar-de-elite-do-reino-unido-casa-se-comnamorado.html. Acesso em: 04 de jul. 2019.

UOL. 2010. Superior Tribunal Militar pune com aposentadoria tenente-coronel gay que teve caso com subordinado. Disponível em: http://gonline.uol.com.br/site/arquivos/ estatico/gnews/gnews_noticia_23505.htm. Acesso em: 04 de jul. 2019.

UOL. 2018. Ordem nas Forças Armadas é expurgar LGBTs, diz criador de ONG que atende vitimas de homofobia. Disponível em: https://noticias.uol.com.br/cotidiano/ ultimas-noticias/2018/07/18/ong-atende-vitimas-de-homofobia-nas-forcas-armadasordem-e-para-lgbts-serem-expurgados.htm. Acesso em: 24 de ago. 2019.

UOL. 2018. Vice de Bolsonaro, general exalta legado da ditadura e ataca "ativismo gay". Disponível em: https://noticias.uol.com.br/politica/eleicoes/2018/noticias/2018/08/08/ vice-bolsonaro-general-mourao.htm. Acesso em: 04 de jul. 2019.

VERBICARO SOARES, D. “Transgêneros e o direito ao voto cidadão de 2018 no Brasil”. In.: Bagoas - Estudos gays: gêneros \& sexualidades, v. 12, n. 19, pp. 241-270, 2018.

VERBICARO SOARES, Douglas. "A condenação histórica da orientação sexual homossexual - as origens da discriminação à diversidade sexual humana: violaçôes aos direitos sexuais - reflexos do Brasil Colônia ao Século XXI”. In: Revista LatinoAmericana de Direitos Humanos - HENDU. V. 7, número 1, pp.50-64, 2016.

VERBICARO SOARES, Douglas. "O estudo da orientação homossexual pensado nos Direitos Humanos e na sociedade brasileira”. In.: Revista Bagoas - Estudos gays, gênero \& sexualidades. V. 13, no 20, pp.121-163, 2019.

VERBICARO SOARES, Douglas. Homossexualidade e Forças Armadas. A busca pela efetividade dos Direitos Humanos no Brasil. Tesina del Programa de Doctorado Pasado y Presente de los Derechos Humanos, Universidad de Salamanca - USAL, Salamanca, España, 2011, 233 p.

VERBICARO SOARES, Douglas. La libertad sexual en la sociedad: especial referencia a la homosexualidad en las Fuerzas Armadas Brasileñas. Tesis Doctoral del Programa de 
Doctorado Pasado y Presente de los Derechos Humanos, Universidad de Salamanca USAL, Salamanca, España, 2015, 791 p.

VERBICARO SOARES, Douglas; CRUZ, Rivetla. "Históricas influências artísticas na formação de ideários sobre a orientação homossexual na sociedade brasileira”. In.: Revista Pensamento Jurídico - FADISP. Vol.12, no 2, jul./dez., pp. 281-307, 2018. 